\title{
Syrian Refugees and Peaceful Coexistence: Dining Spaces as Contact Points ${ }^{1}$
}

\author{
H. Bahadır Akın* \& Yılmaz Seçim** \& Şeyma Akın***
}

\begin{abstract}
Due to the civil war in Syria, Turkey has experienced a flow of refugees affecting many regions within the country since 2011 . Konya -as one of the major cities in the countryreceived more than one hundred thousand people, thus being one of the big cities confronted with problems related to immigration. This study is based on the idea that the prejudice and negative attitudes can be reduced by increasing contact points among refugees and locals. With the assertion that along with routine daily relationships, places for dining -which are one of the first entrepreneurial initials of refugees- are ideal places for contact for these groups. A survey was carried out in Konya with 423 locals and four interviews were conducted with Syrian restaurant owners. The results of MANOVA show that besides having any type of contact, visitors of the restaurants run by foreigners have less negative perceptions towards Syrian refugees.
\end{abstract}

Keywords: Contact, Syrian Refugees, Prejudice, Konya, Migrant restaurants, Immigration.

\section{Suriyeli Sığınmacılar ve Barış içinde Birarada Yaşama: Temas Noktası Olarak Yeme} İçme Mekânları

Öz

Suriye'deki iç savaş sebebiyle, 2011 yllından bu yana Türkiye pek çok bölgesini etkileyen bir sığınmacı akımıyla karşı karşıyadır. Ülkenin büyük şehirlerinden biri olan Konya yüz binin üzerinde sığınmacı gelişiyle uzun zamandır göçten kaynaklanan problemlerle yüzleşmektedir. Bu çalışma, zaruri göçle ülkeye gelenlere karşı sergilenen önyargı ve olumsuz tutumların, sığınmacılarla yerel halk arasındaki temas noktalarının arttırılmasıyla azalacağı fikri üzerine kurgulanmıştır. Günlük rutin ilişkiler yanında, çeşitli ülkelerden sığınmacıların genelde ilk ticari girişimleri olan yeme içme mekanlarının, bu çalışmada tatılıı ve lokantaların, gruplar arasında temas için ideal noktalar olduğu düşünülmektedir. Konya'da -bir proje kapsamında- bu konuda yerel halktan 423 kişi ile bir anket gerçekleştirilmiş, ayrıca dört Suriyeli yeme içme mekanı sahibiyle de temas ve Türklerin ilgisi üzerine mülakatlar yapılmıştır. Araştırmada temel olarak nicel verilerin temasa ilişkin sorularda farklılık gösterip göstermediği varyans analizi kullanılarak anlaşılmaya çalışılmıştır. MANOVA sonuçları genel olarak temasın ötesinde, yabancıların işlettiği mekânları ziyaret edenlerin Suriyelilere karşı daha düşük olumsuz algıya sahip olduğunu göstermektedir.

Anahtar Kelimeler: Temas, Suriyeli Sığınmacılar, Önyargı, Konya, Göçmen lokantaları, Göç.

'The data collection process of this work was supported by Necmettin Erbakan University Scientific Research Projects unit (BAP) under Grant (number 181222002) which was conducted by the first two authors. The emphasis on contact hypothesis is the contribution of the third author. The paper was previously presented orally in ICSES 2018 Congress, Budapest and its abstract was printed in the book of abstracts. No potential conflict of interest was reported by the authors.

\begin{tabular}{|c|}
\hline 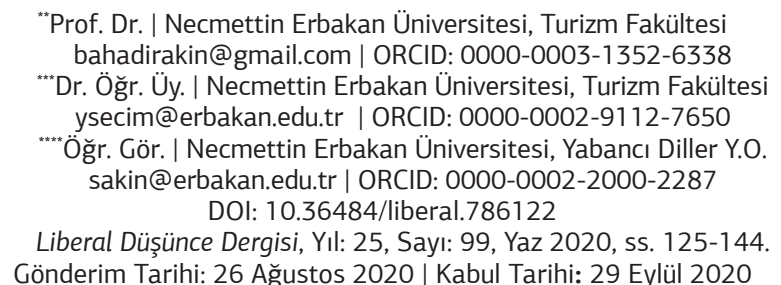 \\
\hline
\end{tabular}




\section{Introduction: The Refugee Crisis in Turkey}

The civil war has led to huge migration waves from Syria to especially neighbouring countries since 2011 and Turkey has experienced a refugee problem especially in bordering regions but also in Istanbul and other big cities (for details, see Akcapar \& Simsek, 2018; Alp, Apiş, Hazneci, Küçükçavuş \& Ertunç, 2018; Erdoğan, 2015; Erdoğan, 2017; İçduygu \& Şimşek, 2016; Kirişçi, 2014). These migration waves were first considered as a humanitarian crisis; however, their settling down in cities and their participation in economic life, and the increasing governmental expenses caused hostility and even hate among Turks from different ideological backgrounds towards refugees over the past years. Due to ongoing conflicts in Syria, it seems that new waves of forced migration will be experienced from Syria to Turkey. Besides, Turkey is a more stable country and a migration culture is arisen as mentioned by Sirkeci (2017) "emerging Turkish-Syrian culture of migration would be just another driver to maintain flows from Syria to Turkey in the near future" (p. 138). On the other hand, with public messages of statesmen made recently, one can notice the change in discourse from considering Syrians as guests to the inability to admit more Syrian refugees and even allowing them to continue to immigrate to Europe by opening borders. The change in discourse is to an extend related to economic conditions and at the same time this hostility towards Syrians harms the ruling Justice and Development Party (Ak Parti) in its domestic policies.

Konya is known as a relatively pious and conservative city has a population of more than two million and a deep-rooted history. It has a significant industry based on production and is integrated with the outer world. Furthermore, Konya is the only metropole that had the highest support for the Justice and Development Party in the latest elections. Approximately $70-80 \%$ of the population -a much higher rate than the average of the rest of the countryfavours conservative parties. Official figures show that about 110.000 Syrian refugees have settled in Konya since 2011, which makes about 5 percent of the urban population (İstatistikler, Geçici Koruma, 2019). Syrian refugees are settled by the Directorate of Migration Management to certain areas within the city. They make their living by working as cheap labour in various fields, but some has their own small businesses such as restaurants.

Easy to say that local people of Konya have -to some extent- a negative perception (for example see Koyuncu, 2018: 185; Quadır \& Çimen, 2018: 337) towards Syrians as it is the case probably in many parts of Turkey (Karataş, 2015; Özdemir, 2017; Taştan, Haklı \& Osmanoğlu 2017; Tümeğ, 2018) and 
even getting worse according to a recent survey (Sade, 2019). It is highly likely that a great part of the Syrians who have been living in Konya for about 8 years will not return to their country at least in the short or medium-term. Children of these people started school here, they set up their lives here, and there are no signs that the issues in Syria will be settled soon. Therefore, overcoming prejudice and negative perceptions of locals and Syrians towards each other will lead to better policy making for the future of both groups and will smooth the path for policies of the Turkish government.

This study is based on the idea that increasing contact of both groups will have an effect on the overcoming or decreasing prejudice. Spaces which enable easier contact to the other group are mainly either related to work in some way (such as repairs, gardening in households or workplaces) or places for dining. This study assumes that especially Turks with strong bias against Syrians will be affected positively when visiting dining places owned by Syrians, and when having a simple trade or voluntary relationship. Thus, a survey has been conducted to understand this phenomenon.

\section{Contact Hypothesis and Its Implication for the Refugee Problem}

In this study, we refer to Gordon W. Allport's intergroup contact theory, though it needs to be pointed out that it is not a study based on the theory. Allport's intergroup contact theory (1954) is very prominent, applied broadly and developed within many disciplines. In his book "The Nature of Prejudice" of 1954, where he discusses concepts around prejudice in detail, he gives a broad look and handles issues like values and judgements, group formations and how they shape our perceptions, and on what levels group differences are perceived. He also differentiates between types of contact and sentiments it arouses, and evaluates ways to overcome tensions and prejudice. Furthermore, Allport has a detailed analysis on how contact changes, and thus explores group formations and in what way values shape them. He also handles differences, what factors lead to these differences and how stereotypes are formed. Then, he looks into various stages of human development and whether and how intergroup contact leads to a better understanding. As stated before, the aim of this study is not to provide a detailed analysis of the intergroup contact theory, but some concepts, factors and analysis related to the theory will handled briefly and discussed in the conclusion part of this paper. Some concepts and approaches of the theory will be used to understand the phenomenon as described above. 
Allport (1954: 262-263) maintains that contact does not always lead to friendly relationships and supports his view by referring to the Jews in Germany in the 1800s because the period was a peaceful one but could not prevent the Holocaust. To understand this phenomenon, he classifies the characteristics of contact and categorizes them in terms of quantitative and qualitative aspects. Thus, aspects like frequency, duration, number of persons who are involved and variety; and status of members, status of the group, status of the relationship, type of relationship etc., all play an important role in determining the nature of the contact. However, there are also determiners related to the context of the contact; thereby, factors like segregation or voluntary contact determine the outcome of the contact. Another significant classification of Allport is the area of contact, because contact related to occupation, religion or residence will all have a different impact on the nature of contact.

There have been many studies based on Allport's contact theory, especially over the past twenty years. One might say that each of them has a different approach on how to implement the theory; thus, some explore the effects of various factors on the outcomes of intergroup contact, others analyse the differences among types of groups or some choose to look into cross-national issues to understand intergroup contact. Therefore, many scholars used Allport's intergroup contact theory to carry out studies on how contact affects our perception and behaviour towards the other. One of the scholars who needs to be mentioned in this context is certainly Pettigrew. In his article "Intergroup contact theory" (1998), he outlines Allport's theory, refers to studies based on the theory in the 70s, 80s and 90s and points out that the majority of them provide positive results of contact (1998: 68). He further determines which aspects need to be enhanced for the theory to be strengthened. Thus, he defines four main areas that need to be addressed and proposes some methods for researches in the field. For instance, he claims that there is no mention about the process of contact and that the problem of generalization is not properly elaborated. He also stresses the importance of psychological and social factors, highlighting that emotions play an important role in contact (1998: 70-73). Besides, Pettigrew (1998: 69) draws attention to the need for further research, for instance in terms of longitudinal studies; which is taken into consideration with later studies, an example of which is by Vezzali, Giovannini and Capozza (2010). In that sense, it is possible to say that later studies are usually based on Pettigrew's analysis. Pettigrew himself, along with Tropp, continued his studies on intergroup contact theory and focussed on issues related to implementation of the theory (Pettigrew \& Tropp, 2006; Tropp \& Pettigrew, 2005). For instance, they analysed studies in order to understand 
problems in the implementation of the theory and how the results of such studies can be extended and generalised so it is possible to apply it to other studies. Therefore, there have been many studies related to conflict and contact, thus leading to different theories and approaches on how to handle them. Böhm, Rusch and Baron (2018: 12-13) address this issue and point out in their article that there is a need for a common semantic framework, because there are various studies on conflict which apply different types of theory, and for an integration of theories and methods from other disciplines.

Many studies focus on majority and minority group perceptions and relations because they usually provide grounds for prejudice and hostile behaviour. A study which focussed on the relation between majority and minority group and their perceptions towards each other was conducted by Sarigil and Karakoç (2016). Here, they tried to understand how religious identification, (ethno-) nationalism and intergroup contact affect the relationship between Turks and Kurds in Turkey. They found that although religion is an overarching element for these groups, it has got no significant positive effect in overcoming bias and prejudice (2016: 4). A further significant result was that Turks who align themselves with the Turkish state, have stronger national identification or tend to vote for MHP (Nationalist Action Party, a right-wing political party) have lower ethnic tolerance (2016: 11-13). However, this study also reveals that more contact leads to more positive outcomes.

Intergroup studies have mainly focussed on the relationship between the majority and minority groups and their perceptions and attitudes toward each other. Hendriks, van Doorn and van Ewijk (2015) address this issue from a different angle that is, they focus on attitudes between minority groups here between Turks and Moroccans living in the Netherlands to understand inter-minority attitudes. They found out that compared to Moroccans, Turks have more social distance. They also discovered that strong ethnic identification seemed not relevant for outgroup attitudes. Furthermore, the study revealed that strong identification with the host society led to a decrease in social distance towards ethnic groups. In general, it provided proof that with more contact, social distance seemed to decrease. In this study, we tried to understand the relationship between the majority group, here locals, and the minority group, that is Syrian refugees.

\section{Dining Spaces as Contact Points}

Food cannot be simply defined as something that stills our hunger because it encompasses many aspects of life and as Takenaka (2017: 119) mentions 
"provides a strategic lens to study this nebulous aspect of immigrant integration... Food is also central to identity and identity making, both at the individual and national levels." Therefore, food has the ability not only contributing to identity building but also to overcoming prejudice and building bridges.

There are certainly many ways to build up contact and relationships; e.g. a religious minority might join the community by going to their centres. However, the easiest way to "connect" seems to be through eating and drinking that this enables us to include and welcome everyone no matter what the background is. Eating and sharing foods also reflects "a willingness to share many other things" (Oussedik, 2012: 60). Thus, gastronomy represents an access point to explore other cultures (McGregor \& Ragab, 2016: 13). Having contact with the "other" group is certainly possible through other means, which is the case in Turkey with migrants working as plumbers or unqualified workers. However, food and restaurants have a less hierarchical structure, which is it can bring all types of people together without pointing at their social status. Therefore, we can see numerous projects and studies aiming to bring different people together with a focus on food (Arvela, 2013; Social, 2016). The idea that migration brings along cultural variety especially through food is quite wide-spread (Testa, 2017). This can be observed in many cities which have a high percentage of migration. Thus, Palermo e.g. is proud with its history of migration (Steavenson, 2018) and provides a rich variety of eating opportunities. It is even described as "less a melting pot of assimilation than as layers of different cultures” (Steavenson, 2018, par. 14), embracing the cultural variety especially in terms of food. Food can also help to overcome prejudice, this can be through food festivals (Frayer, 2015) but also by going to restaurants of the "other" group, which in this case are migrants and locals.

It is easier to bring people together and build bridges through food, but at the same time provides an area where people can find jobs easier compared to other sectors. It might further create a new market, thus promoting goods they provide and at the same time enhancing job opportunities for migrants (Arvela, 2013: 38). Food seems to be helpful in understanding others, because they might show the similarities between cultures; this might have been the case in Konya too because there certainly are similarities between locals and Syrians. However, it needs to be stressed that the case in our study might prove different, that is many locals do not perceive the two cuisines as similar. It is not possible to speak of a variety of "foreign" food in Konya, thus making any other food look "strange" to the locals. Nevertheless, food and therefore 
restaurants seem to be a point of contact because it has the capacity to bring all types of people together.

\section{Methods}

The study is based on the data collected through a survey on local residents in Konya, and interviews with Syrian restaurant owners. Since the study is supported by Necmettin Erbakan University Scientific Research Projects Office, the number of questionnaires was limited to the project budget. A survey, -based on a stratified sample and conducted by a professional firm- comprising of questions on demography, preference of restaurants, and perceptions was carried out with 423 Turkish participants in year 2018, which is roughly a sufficient sample for such a survey, taking the statistical method used into account. In the questionnaire, the Turkish equivalent of "immigrant", which is more common, was used instead of "refugee" in order to make the term more understandable and we preferred "immigrant" instead of the word "Syrian" because it is a delicate issue in the city. Besides, with the help of two Syrians speaking Turkish, four Syrian restaurant owners were interviewed and the obtained data was used to support the survey. Demographic data are presented in Table 1.

Table 1 Demographic Data

\begin{tabular}{llllll}
\hline Gender & Frequency & $\%$ & Education & Frequency & $\%$ \\
Male & 259 & 61.2 & None or primary & 49 & 11.8 \\
Female & 164 & 38.8 & Secondary-High S. & 127 & 30.6 \\
Age & Frequency & $\%$ & College/University & 181 & 43.6 \\
20 or younger & 42 & 9.9 & Graduate & 58 & 14.0 \\
$20-24$ & 83 & 19.6 & Marital Status & Frequency & $\%$ \\
$25-29$ & 86 & 20.3 & Married & 251 & 60.2 \\
$30-34$ & 56 & 13.2 & Single & 166 & 39.8 \\
$35-39$ & 41 & 9.7 & Monthly Income & Frequency & $\%$ \\
39 or older & 115 & 27.2 & Less than 1000 TL & 75 & 19.5 \\
Occupation & Frequency & $\%$ & $1001-2000$ & 81 & 21.0 \\
Jobless & 44 & 11.1 & $2001-3000$ & 93 & 24.2 \\
Housewife & 70 & 17.6 & $3001-4000$ & 66 & 17.1 \\
Public Sector & 94 & 23.7 & $4000-5000$ & 39 & 10.1 \\
Private Sector & 140 & 35.3 & More than 5000 TL & 31 & 8.1 \\
Self Employed & 49 & 12.3 & & & \\
\hline
\end{tabular}




\section{Dependent and Independent Variables}

In order to measure the various dimensions of perception of locals towards Syrians which will also give an idea on prejudice, a scale of 28 items were designed; 12 items of the scale were taken from "Social adaptation in Turkey: refugees and hosting society online survey" (Türkiye'de sosyal uyum, n.d) the other items were developed by the researchers. The items were laid out in a " 1 totally disagree- 5 totally agree" range. We performed an Exploratory Factor Analysis to determine the factors related to the perceptions of local people toward refugees (Extraction method PCA, with Varimax rotation). 5 items were removed from analysis because of factor loads lower than 0.50 or because of loading to more than one factor. Furthermore, although there was a fourth dimension with three items, one item which was incoherent in itself was removed from the scale, and this dimension reduced to two items was not included in the analysis. The sample size for the scale is adequate (KMO $=0.93$, Bartlett's Test of Sphericity 6361.80, $p<0.00$ ).

Consequently, a scale of 21 items and 3 factors was used to analyse the perception of locals toward refugees. The first factor which was labelled as "Positive Attitude Toward Refugees (PA)" comprised of 7 items that explained 37.90 per cent of the variance with factor loadings from 0.59 to 0.89 , the second factor named "Loathing Refugees (LR)" involving 8 items that explained 13.28 per cent of the variance with factor loadings from 0.63 to 0.77 and third factor which was named as "Searching Coherence (SC)" consisting 6 items explaining 7.02 per cent of variance with factor loadings from 0.61 to 0.69 . The Cronbach's Alpha values factors are calculated as $0.90,0.86$ and 0.84 respectively. The Confirmatory Factor Analysis which was carried out for the scale indicates a sufficient fit $(\mathrm{X} 2 / \mathrm{DF}=3.03, \mathrm{RMSEA}=0.070, \mathrm{CFI}=0.97, \mathrm{NFI}=0.95$, GFI=0.89, AGFI=0.86) (Hahs- Vaughn, 2017, 453).

The dependent variables of the study are the three factors determined by EFA. The items were converted to one single arithmetic mean for each factor. In sum, the dependent variables are coded as "Positive Attitude toward Refugees (PA)", "Loathing Refugees (LR)" and "Searching Coherence (SC)".

The independent variables were determined by two questions respectively related to the contact of Turks and Syrians. First, within the context of the main research question, it was assumed that having eaten in a restaurant run by refugees would make a difference for Turks in terms of their perception. Eating at a restaurant from a different culture is a conscious choice and only people with positive perceptions are expected to have such a choice. Besides, 
it is believed that a preference like dining can lead to a more positive attitude. So, the first the first IV was formulated as "Having eaten in a restaurant run by refugees (RES)" which has "Yes/No" choices. Then, we tried to see whether any contact has an impact on these DVs, and decided to form the second IV as "Having had any business relationship with refugees (REL)" with "Yes/No" choices. Those responding "Yes" to RES is 9.10 per cent $(\mathrm{N}=38)$, and to REL is 16.5 per cent $(\mathrm{N}=68)$. The percentage of locals having never eaten at a refugee restaurant is 90.9 per cent $(\mathrm{N}=380)$, and of those having never had a business relationship is 83.50 per cent $(\mathrm{N}=343)$.

In sum, the dependent variables are coded as "Positive Attitude toward Refugees (PA)", "Loathing Refugees (LR)" and "Searching Coherence (SC)" and the independent variables as "Having eaten in a restaurant run by refugees (RES)" and "Having had any business relationship with refugees (REL)".

The arithmetic means $(\mathrm{M})$ and standard deviations (SD) were calculated for each factor. These values were calculated as $\mathrm{N}=422, \mathrm{M}=1.99, \mathrm{~S}=1.10$ for "Positive Attitude toward Refugees (PA)", as $\mathrm{N}=421, \mathrm{M}=3.86, \mathrm{~S}=1.06$ for "Loathing Refugees (LR)", as $\mathrm{N}=421, \mathrm{M}=2.27, \mathrm{~S}=1.05$ for "Searching Coherence (SC)". According to this, an overwhelming majority of the Turkish population in Konya has a negative view towards foreigners, whereas positive perceptions and perceptions related to seeking cohesion have a score much lower than the average.

\section{Analysis of Variance}

In the first hand, we observed that there is a significant difference for two Independent Variables "Having eaten in a restaurant run by refugees (RES)" and "Having had any business relationship with refugees (REL)" on three Dependent Variables "Positive Attitude Toward Refugees (PA)", "Loathing Refugees (LR)" and "Searching Coherence (SC)" by performing independent sample t-tests (and non-parametric Mann Whitney-U tests considering the non-normality) for all independent variables $(\mathrm{p}<0.00)$.

However, considering the fact that performing a number of individual tests will inflate the type-I errors because of the high number of dependent variables, we preferred MANOVA instead of a number of independent ANOVAs to see the effects of independent variables in detail and avoid the inflating Type-I errors (Hahs-Vaughn, 2017: 172; Tabachnick \& Fidell, 2018: 246-247). Because it is specified that the strength of MANOVA depends on highly negative or moderate correlations (Tabachnick \& Fidell, 2018: 270), we proceeded 
MANOVA taking our correlation values of three DVs (PA-LI=-0.42**, PA$\mathrm{SC}=0.65^{* *}, \mathrm{LI}-\mathrm{SC}=-0.32 * *$.

In order to perform MANOVA, the prerequisites of independence, multivariate normality and linearity, Homogenitiy of Variances should be provided (Hahs-Vaughn, 2017, 183-185; Tabachnick \& Fidell, 2018: 252-253). For our three dependent variables, we could not provide normality (Saphiro Wilk test, $\mathrm{p}<0.00$ ). As is mentioned above, the negative attitude towards Syrian refugees causes high skewness values and thus a serious deviation from normality. Yet, Tabachnick and Fidell (2018: 253) specifies that normality may be assumed for MANOVA in case of a total $\mathrm{N}=40$ and $\mathrm{N}=10$ for cells. Likewise, Huberty and Olejnik (2006: 138) indicate that the violation of multivariate normality has a lower effect on P value in MANOVA hypothesis tests. Also, Norman (2010) suggests that parametric tests can be used under any circumstances for Likert type scales and arguments asserting the strict prerequisites for analysis of variance, including the normality assumption, are not meaningful at all.

Box's $M$ was calculated for homogeneity of variance, and according to the results of Box's test of equality of variances (The Box's $M=33.10, F=1,746$, $\mathrm{p}=0.02$ ), the equality of covariance matrices for our data can be assumed, because the $\mathrm{p}$ value is not significant at $\mathrm{p}<0.005$ level (Hair, Black, Babin \& Anderson 2014:250, 685-686; Huberty and Petoskey, 2000: 193) or $\mathrm{p}<0.001$ (Tabachnick \& Fidell, 2018: 254).

Although all the tests produce similar results in general, when the assumptions are not totally secured and relatively unbalanced designs (as in our case), it is suggested to use Pillais' Trace (Hahs- Vaughn, 2017: 175). For Independent Variable "Having had any business relationship with refugees (REL)" the MANOVA effect is not statistically significant (Pillais' Trace $=0.14$, $\mathrm{F}=1.84, \mathrm{p}=0.13$ ). For "Having eaten in a restaurant run by refugees (RES)" (Pillais' Trace=0.23, F=3.09, $\mathrm{p}=0.02$ ) and REL*RES (Pillais' Trace=0.24, F=3.32, $\mathrm{p}=0.02$ ) the effects are statistically significant, $\mathrm{p}<.05$. The effect size for RES is 0.02 and 0.02 for REL*RES.

In conclusion, despite the significant differences indicated by independent parametric and non- parametric tests, the results of MANOVA point out that there is not a significant attitude change for Turks who only meet with refugees for any business affair, but a significant change in positive attitudes of people eating at Syrian restaurants. That is, the people eating at refugee restaurants have more positive perceptions towards refugees. Also, meeting refugees for any reason and eating at refugee restaurants together have a positive effect on attitudes for all three dependent variables towards refugees. 


\section{Interviews}

Along with the survey, we carried out interviews with four Syrian refugee restaurant owners on doing business in Turkey and how much Turks show interest to these places. Two of these places are bakery-confectionary type businesses (usually serving and selling "baklava" pastry along with other desserts), one is quite a big restaurant serving different type of dishes including fast-food and kabab, and another fast food restaurant mainly serving chicken dishes. The restaurants are both located in the Şükran district which is highly populated by refugees and the two others are in the city centre close to each other but also not far away from the refugee populated districts.

The interviews were carried out with the help of two Syrian translators, could not be recorded but the answers were written down. They included questions on the interests of local people and their contact with them. In this context the owner of the bigger restaurant stated that only about 5 per cent of the customers were Turkish. The percentage in the chicken fast-food restaurant was about 20 per cent; in the bakeries, on the other hand, Turkish customers made up of about 50 per cent or more. The chicken fast-food restaurant has a second branch in Bosna, a district in Konya mainly inhabited by university students, and here the percentage is about 50 per cent; its branch in the industrial zone has a Turkish customer rate of about 80 per cent. This fact shows that locals tend not to go to restaurants located in "refugee districts". Furthermore, in restaurants within refugee districts the use of credit cards is not very common, but in areas like Bosna where customers are mainly students and in one of the bakeries it was possible to pay by credit card. The menus in both the restaurants and bakeries were completely typical Syrian dishes. All participants expressed that they went through sanitary and hygiene controls of the Turkish state.

Turning back to the survey, when asked in the survey why Turkish people do no tend to go to these restaurants, we came up with several significant findings. The reasons for this were ranked as following (1 for totally disagree to 5 for totally agree) "I am not sure about sanitary issues (hygiene)" ( $\mathrm{N}=351$, $\mathrm{M}=4.36, \mathrm{SD}=1.18)$, "They are located in unsafe areas" $(\mathrm{N}=321, \mathrm{M}=4.13$, $\mathrm{SD}=1.36)$, "They are not to my taste" ( $\mathrm{N}=336, \mathrm{M}=4.09, \mathrm{SD}=1.34)$, "I dislike foreigners" ( $\mathrm{N}=324, \mathrm{M}=3.75, \mathrm{SD}=1.51)$, "I'm not aware of these restaurants" $(\mathrm{N}=315, \mathrm{M}=2.78, \mathrm{SD}=1.75)$ and "I' $\mathrm{m}$ hesitant because of language issues (don't understand Arabic)" (N=317, M=2.45, SD=1.65) 
Therefore, the popularity and the difference in language did not seem to be considered as problematic but hygiene, security, gusto and xenophobia can be evaluated as problems. Besides interviews and specific questions, the responses to open ended questions indicate a serious prejudice and even hatred towards foreigners in general and Syrians in particular. Both the survey and the interviews reveal that Turks do not tend to go to restaurants which are in the Syrian populated districts, and that the reason for this is not only prejudice and hatred, but might be also related to factors like security, hygiene, use of credit cards, and gusto. In that sense, Turks seem to be indifferent to the identity of the restaurant in places with less refugees and where employees are Turks or speak Turkish.

\section{Discussion}

Contact usually leads to positive results although it needs to be pointed out that there a few studies which prove the contrary (e.g. Capozza, Trifiletti, Vezzali \& Favara 2013; Tropp \& Pettgrew, 2006). Various studies with different types of groups conducted in Turkey also show that there is a positive outcome as a result of intergroup contact (Küçükkömürler \& Sakalli-Uğurlu, 2017: 19). Liebkind and Mcalister (1999) went further and studied the effect of extended contacts through peer modelling, and they conducted this research in Finnish middle schools. Here they focused, for example, on the effect of close friendship of an ingroup member with a member of an outgroup as this might have "spill over" effect on others (p. 769). They also discuss various possibilities to implement such relationships. Another study in that direction was done by Žeželj, Ioannou, Franc, Psaltis, and Martinovic (2017), who conducted a study in which they included three post-conflict societies - that is Serbia, Croatia and Cyprus. They analysed online inter-ethnic relations because in divided societies as these, the chance to have face-to-face contact is less likely. Thus, they claimed that having online relationships is a chance, and they came up with positive results - contact leads to better outgroup attitudes.

It is not the scope of this research to discuss every publication on contact theory; nevertheless, some need to be highlighted here as they either have a similar focus like this study or present some significant results to understand contact and it impact. As expected, all studies highlight the impact of contact, but focus on various issues ranging from "present situations" to longitudinal studies, or from minority-majority relations to the nature of contact etc. Amir (1969) is one of the early researchers of intergroup contact theory. In his paper "Contact hypothesis in ethnic relations", he gives a summary of studies rela- 
ted to the field and discusses situational components of contact. Thus, acquaintance potential is significant as it provides the social setting for contact (restaurants in our case), also, when we aim to change the attitudes especially of majority groups, the status of both groups need to be similar since when this is not the case there is the probability that it will strengthen bias. This last point will be handled below because it has an implication to our study and contact with migrants occur on different contexts with different status.

One further study which included the impact of status of groups is the publication by Tropp and Pettgrew (2006) who analysed the differences between minority and majority groups in terms of relationships between contact and prejudice. The reason why they looked at minority and majority groups was to understand how the social status of a group affects the results of contact (2006: 955-956). They figured out that the relationship with minority groups is weaker and concluded that this might be because they are exposed to prejudices and therefore develop more negative attitudes. Another study which tries to understand intergroup relationship and the differences in the outcomes as a result of the status or character of the group was carried out by Capozza et al (2013). In this study, they analysed the potential to reduce outgroup infra-humanisation. They observed that there is a tendency to consider other groups as less human and did a pre-test to evaluate what traits were considered human. In their research they organised two levels of study, one between Italians and the other between southern and northern Italians. They concluded that dehumanisation is probably caused by personal feelings; that is, because people have feelings of anxiety and threat, they might justify their negative attitude due to such feelings.

One further aspect is the cooperation versus competition factor because while cooperation leads to more positive outcomes, competition has the potential to undermine it. The outcome will be more positive if there is normative support, that is support from authorities; and if a need is satisfied with the contact. The nature of the contact also plays an important role; that is it depends on whether it is intimate or superficial. Unsurprisingly, if we expect to overcome prejudice the nature of the contact should be intimate. As the study of McKeown and Dixon (2017) proves even in desegregated schools the potential for superficial contact is there. Here, they focus on some points which seem to be neglected in many studies related to contact (2017: 1, 8). They point out that studies based on structured contact might not reveal the reality, because everyday contact might differ from it. They also maintain that contact might lead to negative experience; even desegregated spaces such as schools might not lead to more positive contact and may cause resegregation 
due to e.g. seating choice in the classroom. A similar outcome can be seen in a study conducted by Czeranowska (2018: 17) in Poland which shows that contact has positive effects on the perception of immigrants; however, it needs to be pointed out that "basic contact" does not contribute to a positive outcome, whereas having a friend from different origins plays a significant role in changing people's ideas related to the "other".

In sum, the nature of contact plays an important role; thus, an intimate or a temporary/ superficial contact did not provide the same positive results. Furthermore, contact between groups and its outcome vary according to the status of the groups. Our study supports this aspect. We asked questions related to contact about restaurant visits and about having any business with Syrian refugees. The reason for these two questions was that Turks and Syrians tend to have very limited contact - which is certainly not the case for children, because they go to school and encounter there. Therefore, one way to meet the other was in restaurants, especially Syrian restaurants, and the other for business. Here, it needs to be pointed out that many Syrian refugees coming to Turkey have a special status according to the Turkish law (Akcapar \& Simsek, 2018: 176-177; Akın \& Akın, 2017: 143). Therefore, most of them do not receive any or a significant income and have to work for a living. Due to the language barrier and other reasons, they work as unskilled workers in the construction sector or the like; so Turkish people encounter Syrians when there is something to be fixed at homes or work. These two encounters have different natures of contact, the latter of which definitely and openly has a hierarchical relationship. An encounter at a restaurant and a contact in a business context are different in terms of the status of the people and therefore, can have a different outcome in overcoming prejudice.

Furthermore, attitudes and behaviour are certainly shaped by various outer factors, but also demographic factors and ideology play an important role and therefore determine the nature and outcome of contact. Kaya and Kayaoğlu tried to understand in their study which factors increase Islamophobic behaviour and how contact affects attitudes. They found out that with increasing age, nationalism and being male have a positive effect on Islamophobic attitude, whereas religiosity, higher education and the size of town seem to decrease such attitude (2017: 62). In their study they also refer to some solutions, such as which group to target and with which groups to work with for support. Such factors need also to be considered in the Syrian refugee case in Turkey; attitudes of people towards them vary especially in terms of ideology. However, prejudice is rooted in many other aspects as well, as can be seen in McBride's (2015) comprehensive report on how to cope with prejudice and 
discrimination. The report classifies causes of prejudice (2015: 10-11); thus, it might have genetic- evolutionary grounds, might be the result of norms, can be strengthened through mechanisms of social influence such as media or education, and can be caused by personal differences. In the Turkish case (related to Syrian refugees), another factor needs to be added - the "collective historical aspect"- because the attitudes towards an "Arab", especially who had historical relations with the Ottoman Empire, is often negative (Jung, 2005). Possibly the reason underlying this is that their ancestors are often labelled as traitors to the Empire so prejudice against "Arabs" has a different dimension in Turkey. The negative perception towards Arabs is an ongoing reality (Küçükcan, 2010), and is even reinforced within the Turkish narrative.

One further problem with contact is that prejudiced people usually avoid contact with members of the outgroup. Binder, Zagefka, Brown, Funke, Kessler and Mummendey (2009: 844), e.g., also stress the impact of prejudice on the characteristic and outcome of contact, because prejudiced people either tend to avoid contact or if they cannot they keep it on a superficial level. This study also underlines the differences between majority and minority groups and claim that there is a tendency to focus on the views of majorities, neglecting those of minorities. According to the same study, contact influences prejudice both in terms of the desire for social distance and negative intergroup emotions (2009: 852-853). A similar situation is true for the Turkish case, people usually tend to avoid contact with migrants or do not seek to have contact thus leading to the continuation of negative attitudes.

The results prove that contact between Turks and Syrian refugees is very limited and shaped by prejudice, making contact and thus decreasing prejudice a problematic matter. However, studies prove that this is not the case in general and that contact has positive effects even with biased people (see Hodson, 2011; Leibbrandt \& Saaksvuori 2012; Schmid, Hewstone, Küpper, Zick \& Tausch, 2014). Communication plays an important role in reducing conflict and communication with rival groups or outgroups proves to be fruitful. 


\section{Conclusion}

Our study aimed at understanding the perceptions of Turks towards Syrians, and how much contact there is between these groups. Hence, it was assumed that dining spaces - besides business and work settings - are suitable spaces for contact and effective to overcome negative attitudes and prejudice. The findings were that prejudice of Turks going to Syrian restaurants was decreased relatively and positive perceptions increased comparatively. Despite a small sample and a few interviews, they supported the fact that all types of contact and especially contact through dining spaces have an impact in overcoming prejudice on both sides. Because the survey was conducted only in Konya and a relatively small sample was used, we suggest more research focusing on contact issue in terms of migration with larger samples in different cities.

It is certainly not possible to support the idea that contact decreases prejudice between Turks and Syrians or that those who are less biased are open to such contact with only one study. Further research needs to be carried out in other cities and with more samples and deeper interviews including various factors related to prejudice. Furthermore, future studies on intergroup contact related to Syrians in Turkey could include various aspects, such as longitudinal studies so it would be possible to understand how much change is possible through contact. Besides, there needs to be more research on from the minority perspective, that is the attitudes and perceptions of migrants need to be studied further.The results of such studies would provide a helpful ground for official institutions and NGOs in order to carry out their activities related to migrants.

The results of this study highlights various issues that need to addressed to handle the matter; these are related to hygiene, considering local taste (such as adding local dishes to their menus) and safety. If these are improved and shared with the locals, both refugees and locals will benefit in terms of economic wealth, more chances of employment. Thus it will contribute to the integration of refugees and decrease of prejudice of Turks towards them. Dining spaces are one of the easiest settings to have contact in daily life, so their accessibility for Turks need to be facilitated. Therefore, it is assumed that in time these dining places, will lead to more contact with their opening in other areas such as shopping malls, shopping streets or more cosmopolitan areas. Furthermore, steps like including the Syrian restaurant owners into the legal system, increasing the use of credit cards, adding meals that appeal more to the Turkish taste or even some Turkish meals to their menus might help to overcome prejudice and lead to more contact. 


\section{References}

Akcapar, S.K. \& Simsek, D. (2018). The Politics of Syrian Refugees in Turkey: A Question of Inclusion and Exclusion through Citizenship. Social Inclusion, 2018, Volume 6, Issue 1: 176-187.

Retrieved from https://www.cogitatiopress.com/socialinclusion/article/view/1323/1323

Akın, Ş., Akın \& H. B. (2017). The Syrian Refugee Crisis and Turkey-EU Relations:

Responses in Politics. Sosyal ve Ekonomik Araştırmalar Dergisi 19 (32): 141-150. Retrieved from http://dergi.kmu.edu.tr/ userfiles/files/17-Bahadır\%20Akın.pdf

Allport, G.W. (1954). The Nature of Prejudice. Addison-Wesley Publishing Company.

Alp, Ç., Apiş, I. Y, Hazneci, H., Küçükçavuş, M. A. \& Ertunç, M.A, (2018). Syrians in Turkey Special Report. Ombudsman Institution of the Republic of Turkey, Ankara. Retrieved from https://www.ombudsman.gov.tr/syrians/special_report.pdf

Amir, Y. (1969). Contact hypothesis in ethnic relations. Psychological Bulletin, 71(5), 319342. DOI: $10.1037 / \mathrm{h} 0027352$

Arvela, P. (2013). Ethnic food: the other in ourselves. In D. Sanderson \& M. Crouch (Eds.), Food: Expressions and Impressions, Oxford, United Kingdom: Inter-Disciplinary Press, pp. 45-56. Retrieved from https://ro.uow.edu.au/cgi/viewcontent.cgi?article=2109\& context=Ihapapers

Binder, J., Zagefka, H., Brown, R., Funke, F., Kessler, T. \& Mummendey, A. (2009). Does Contact Reduce Prejudice or Does Prejudice Reduce Contact? A Longitudinal Test of the Contact Hypothesis Among Majority and Minority Groups in Three European Countries. Journal of Personality and Social Psychology, Vol. 96, No. 4, 843-856.

Böhm, R., Rusch, H. \& Baron, J., (2018). The psychology of intergroup conflict: A review of theories and measures, Journal of Economic Behavior and Organization, (in press): 1-16. https://doi.org/10.1016/ j.jebo.2018.01.020

Capozza, D., Trifiletti, E., Vezzali, L. \& Favara, I. (2013). Can intergroup contact improve humanity attributions? International Journal of Psychology, Vol. 48, No. 4, 527-541.

Czeranowska, O. (2018). Attitudes towards immigrants of other race or ethnic origin - Polish dataset from round 7 of the European Social Survey, Centre of Migration Research Research Papers Working Papers 109/167, Retrieved from

http://www.migracje.uw.edu.pl/wp-content/uploads/2018/07/WP109167.pdf

Erdoğan, M. M. (2017). Urban Refugees from "Detachment" to "Harmonizatıon" Syrian Refugees and Process Management of Municipalities: The Case of Istanbul. Marmara Belediyeler Birliği Kültür Yayınları. Retrieved from http://marmara.gov.tr/UserFiles/ Attachments/ 2017/05/09/5c68e8fe-6a35-4411-88f1-2f685bf4b1da.pdf

Erdoğan, M.M. (2015). Türkiye'deki Suriyeliler: Toplumsal Kabul ve Uyum- Syrians in Turkey: Social Acceptence and Integration. Hacettepe Üniversitesi Göç ve Siyaset Araştırmaları Merkezi, Ankara. Retrieved from http://fs.hacettepe.edu.tr/hugo/ dosyalar/HUGO-REPORT- SyriansinTurkey.pdf

Frayer, L. (2015). Budapest Foodies Hope Cuisine Can Help Heal Anti-Migrant Prejudice.

NPR, October 6, 2015, Retrieved from https:/www.npr.org/sections/thesalt/2015/10/06/ 445999732/budapest-foodies-hope-cuisine-can-help-heal-anti-migrant-prejudice

Geoff, N. (2010). Likert scales, levels of measurement and the "laws" of statistics, Adv in 
Health Sci Educ 15: 625-632. doi: 10.1007/s10459-010-9222-y.

Göç İdaresi, 2019. İstatistikler, Geçici Koruma (07 November 2019) Retrieved from https:// www.goc.gov.tr/ gecici-koruma5638

Hahs-Vaughn, D. L. (2017). Applied multivariate statistical concepts, Routledge. Hair, J. F. Jr., Black, W. C., Babin, B. J. \& Anderson, R. E. (2014). Multivariate Data Analysis. Seventh Edition, Pearson Education Limited.

Hendriks,P., van Doorn, Lia \& van Ewijk, Hans J.P. (2015). Turkish and Moroccan Dutch professionals in social work. European Journal of Social Work, DOI:10.1080/13691457.20 15.1030362

Hodson, G. (2011). Do ideologically intolerant people benefit from intergroup contact? Current Directions in Psychological Science 20 (3) 154-159. https://doi.org/10.1177/ 0963721411409025

Huberty, C. J., Olejnik, S. (2006). Applied MANOVA and discriminant analysis, 2nd ed. Wiley Interscience.

Jung, D. (2005). Turkey and the Arab World: Historical narratives and new political realities. Mediterranean Politics, Vol.10, No.1, 1-17. https://doi.org/10.1080/ 1362939042000338818

Karataş, M. (2015). Türk yazılı basınında Suriyeli sığınmacılar ile halk arasındaki ilişkinin incelenmesi. Göç Araştırmaları Dergisi, The Journal of Migration Studies, Cilt: 1, Sayı: 2, Temmuz-Aralık: 112-151. Retrieved from http://www.gam.gov.tr/files/sayi2-4.pdf

Kaya, A., Kayaoğlu, A. (2017). Individual determinants of anti-muslim prejudice in the EU15. Uluslararası Illişkiler, Volume 14, No. 53: 45-68. Retrieved from https://www.uidergisi.com.tr/source/JUI_2017_53_45_68.pdf

Kirişçi, K. (2014). Syrian refugees and Turkey's challenges: Going beyond hospitality. Brookings, Washington. Retrieved from https://www.brookings.edu/wp-content/uploads/2016/06/Syrian-Refugees-and-Turkeys-Challenges- May-14-2014.pdf

Koyuncu, A. (2018). Misafirlikten vatandaşlığa Türkiye'de geçici koruma altındaki Suriyeliler. Middle East Journal of Refugee Studies, Yaz 2018, (3)2: 171-195. DOI: 10.12738/ mejrs.2018.3.2.0009

Küçükcan, T. (2010). Arab image in Turkey. SETA Research Report, No.1. Retrieved from http://file.setav.org/Files/Pdf/arab-image-in-turkey.pdf

Küçükkömürler, S. \& Sakalli-Uğurlu, N. (2017). Gruplararası ilişkileri düzenlemede sosyal temas kuramları: gruplar arası, yayılmacı ve hayali temas. Nesne, 5(9), 1-31. Retrieved from http://www.nesnedergisi. com/makale/pdf/1466592418.pdf

Lauren, F. (2015). Budapest foodies hope cuisine can help heal anti-migrant prejudice. NPR, October 6, 2015. Retrieved from https://www.npr.org/sections/thesalt/2015/10/06/ 445999732/budapest-foodies-hope-cuisine-can-help-heal-anti-migrant-prejudice

Leibbrandt, A. \& Saaksvuori, L. (2012). Communication in intergroup conflicts. European Economic Review 56, 1136-1147. https://doi.org/10.1016/j.euroecorev.2012.05.003

Liebkind, K. M. \& Alfred, L. (1999). Extended contact through peer modelling to promote tolerance in Finland. European Journal of Social Psychology, 29, 765-780. https://doi. org/10.1002/(SICI)1099-0992(199908/09)29:5/6<765::AID-EJSP958>3.0.CO;2-J

McBride, M. (2015). What works to reduce prejudice and discrimination? A review of the evidence. Scottish Government Social Research. Retrieved from https://www.gov.scot/publications/works-reduce-prejudice-discrimination-review-evidence/, retrieved 1.8.2019. 
McGregor, E. \& Nora, R. (2016). The role of culture and the arts in the integration of refugees and migrants. European Expert Network on Culture and Audiovisual (EENCA), Retrieved from https://www.merit. unu.edu/publications/uploads/1473335881.pdf

McKeown, S. \& Dixon, J. (2017). The 'contact hypothesis': Critical reflections and future directions. Social and Personality Psychology Compass, 11(1), [e12295]. https://doi. org/10.1111/spc3.12295

Oussedik, S. (2012). Food and cuisine: part of the migration process. Quaderns de la Mediterrània, 17, pp.55-60 Retrieved from https://www.iemed.org/observatori/arees-danalisi/ arxius- adjunts/qm-17-originals/qm170ussedik. pdf-fr/at_download/file

Özdemir, E. (2017). Suriyeli mültecilerin Türkiye'deki algıları. Savunma Bilimleri Dergisi, The Journal of Defense Sciences Mayı/May 2017, Cilt/Volume 16, Sayı/Issue 1: 115-136. https://doi.org/10.17134/ khosbd. 405253

Pettigrew, T. F. (1998). Intergroup contact theory. Annual Review of Psychology, 49:65-85. https://doi.org/ 10.1146/annurev.psych.49.1.65

Pettigrew, T. F. \& Tropp L. R. (2006). A meta-analytic test of intergroup contact theory. Journal of Personality and Social Psychology, Vol. 90, No. 5, 751-783. DOI:10.1037/00223514.90.5.751

Quadır, S. E. \& Kabaklı, L. Ç. (2018). Türk vatandaşlarının Suriyeli sığınmacılarla ilgili görüş̧leri (Konya ili örneği). Üçüncü Sektör Sosyal Ekonomi,53 (2): 327-345. DOI:10.15659/3. sektor- sosyal-ekonomi.18.05.906

Sade, G. (2019). Suriyeli sığınmacılara bakış 3 yılda büyük oranda olumsuz yönde değişti, Retrieved from https:/tr.euronews.com/2019/07/29/suriyeli-siginmacilara-bakis-3-yilda-buyuk- oranda-olumsuz-yonde-degisti

Sarigil, Z. \& Karakoc, E. (2016). Inter-ethnic (In)tolerance betweenTurks and Kurds: Implications for Turkish Democratisation. South European Society and Politics, p. 1-20. http:// dx.doi.org/10.1080/ 13608746. 2016.1164846

Schmid, K., Hewstone, M., Küpper, B., Zick, A. \& Tausch, N., (2014). Reducing aggressive intergroup action tendencies: effects of intergroup contact via perceived intergroup threat, Aggressive Behavior, Volume 40, p. 250-262. DOI:10.1002/ab.21516

Sirkeci, I. (2017). Turkey's refugees, Syrians and refugees from Turkey: A country of insecurity. Migration Letters. 14. 127-144. Doi 10.33182/ml.v14i1.321.

Social Innovation Europe (2016). Options foodlab: How food making and sharing is supporting migrant integration in Greece. Retrieved from https://socialinnovationexchange. org/ insights/options-foodlab-how-food-making-and-sharing-supporting-migrant-integration-greece

Steavenson, W. (2018). 'Our island is like a mosaic': how migrants are reshaping Sicily's food culture. The Guardian. Retrieved from https:/www.theguardian.com/world/2018/ jun/17/our-island-is- like-a-mosaic-how-migrants-are-reshaping-sicilys-food-culture

Tabachnick, B. \& Fidell G. L. S. (2018). Using multivariate statistics. Pearson, Boston.

Takenaka, A. (2017). Immigrant integration through food: Nikkei cuisine in Peru. Contemporary Japan, 29:2, 117-131. https://doi.org/10.1080/18692729.2017.1351022

Taştan, C., Haklı, S. Z. \& Osmanoğlu, E. (2017). Suriyeli sığınmacılara dair tehdit algısı: önyargılar ve gerçekler. Polis Akademisi Yayınları.

Testa, G. (2017). A taste of the world: the global importance of food and dining, Retrieved 
from https://pos.toasttab.com/blog/a-taste-of-the-world-the-global-importance-offood-and-dining

Tropp, L. R \& Pettigrew, T. F. (2005). Relationships between intergroup contact and prejudice among minority and majority status groups. Psychological Science, Volume 16, Number 12, 951-957. DOI: 10.1111/j.1467-9280.2005.01643.x

Tümeğ, D. (2018). Türk halkının Suriyeli sığınmacı/mülteci algısı mevcut durum, saha çalışması ve politika önerileri, Türksam Yayınları, Ankara. Retrieved from http://turksam.org/dosyalar/2018/07/TU\%CC\%88 RKSAM-Rapor-1\%CC\%87c\%CC\%A7.pdf

Türkiye'de Sosyal Uyum: Mülteci ve ev sahibi topluluk online anketi (n.d). Retrieved from https://docs.wfp.org/api/documents/WFP-0000039743/download/

Vezzali, L., Giovannini, D. \& Capozza, D. (2010). Longitudinal effects of contact on intergroup relations: the role of majority and minority group membership and intergroup emotions. Journal of Community \& Applied Social Psychology 20: 462-479. https://doi. org/10.1002/casp.1058

Žeželj, I. L., Ioannou, M., Franc, R., Psaltis, C. \& Martinovic, B. (2017). The role of inter- ethnic online friendships in prejudice reduction in post-conflict societies: Evidence from Serbia, Croatia and Cyprus, Computers in Human Behavior 76, p. 386-395. https://doi. org/10.1016/j.chb.2017.07.04 